\title{
Ion Sorption onto Hydrous Ferric Oxides: Effect on Major Element Fluid Chemistry at Äspö, Sweden
}

Carol J. Bruton

Brian E. Viani

\section{RECEIVED \\ JUL 22 1996 \\ OSTI}

This paper was prepared for submittal to the

Second Äspö International Geochemistry Workshop

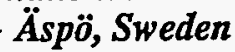

June 6-7, 1995

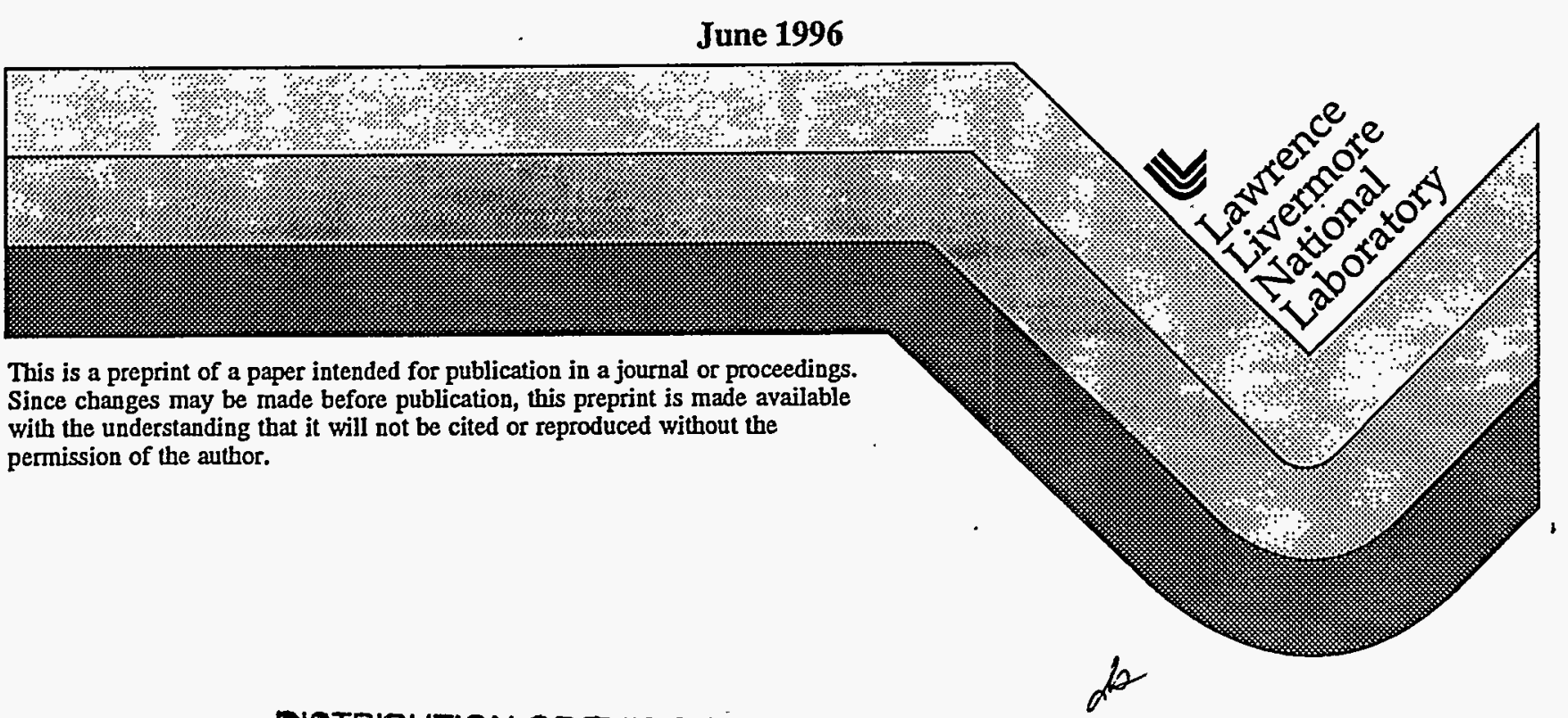

DSTRIBUTION OF THIS DOCUMENT IS UNLIMITED 


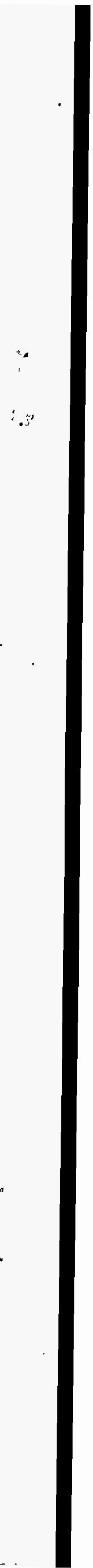

This document was prepared as an account of work sponsored by an agency of the United States Government. Neither the United States Government nor the University of California nor any of their employees, makes any warranty, express or implied, or assumes any legal liability or responsibility for the accuracy, completeness, or usefulness of any information, apparatus, product, or process disclosed, or represents that its use would not infringe privately owned rights. Reference herein to any specific commercial product, process, or service by trade name, trademark, manufacturer, or otherwise, does not necessarily constitute or imply its endorsement; recommendation, or favoring by the United States Government or the University of California. The views and opinions of authors expressed herein do not necessarily state or reflect those of the United States Government or the University of California, and shall not be used for advertising or product endorsement purposes. 


\section{DISCLAIMER}

Portions of this document may be illegible in electronic image products. Images are produced from the best available original document. 



\title{
ION SORPTION ONTO HYDROUS FERRIC OXIDES: EFFECT ON MAJOR ELEMENT FLUID CHEMISTRY AT ÄSPÖ, SWEDEN
}

Carol J. Bruton and Brian E. Viani

Lawrence Livermore National Laboratory

Livermore, California 94550 USA

\begin{abstract}
The observed variability of fluid chemistry at the Äspö Hard RockLaboratory is not fully described by conservative fluid mixing models. Ion exchange may account for some of the observed discrepancies. It is also possible that variably charged solids such as oxyhydroxides of $\mathrm{Fe}$ can serve as sources and sinks of anions and cations through surface complexation. Surface complexation reactions on hydrous ferric oxides involve sorption of both cations and anions.
\end{abstract}

Geochemical modeling of the surface chemistry of hydrous ferric oxides (HFOs) in equilibrium with shallow HBH02 and deep KA0483A waters shows that HFOs can serve as significant, pH-sensitive sources and sinks for cations and anions. Carbonate sorption is favored especially at below-neutral pH. A greater mass of carbonate is sorbed onto HFO surfaces than is contained in the fluid when $10 \mathrm{~g}$ goethite, used as a proxy for HFOs, is in contact with $1 \mathrm{~kg} \mathrm{H}_{2} \mathrm{O}$. The masses of sorbent required to significantly impact fluid chemistry through sorption/desorption reactions seem to be reasonable when compared to the occurrences of HFOs at Äspö. Thus, it is possible that small changes in fluid chemistry can cause significant releases of cations or anions from HFOs into the fluid phase or, alternately, result in uptake of aqueous species onto HFO surfaces.

Simulations of the mixing of shallow HBH02 and native KA0483A waters in the presence of a fixed mass of goethite show that surface complexation does not cause the concentrations of $\mathrm{Ca}, \mathrm{Sr}$, and $\mathrm{SO}_{4}$ to deviate from those that are predicted using conservative mixing models. Results for $\mathrm{HCO}_{3}$ are more difficult to interpret and cannot be addressed adequately at this time.

In future work, the effect of surface complexation on the partitioning of trace elements such as uranium between HFOs and ground water will be addressed.

INTRODUCTION

Laaksoharju (1994) noted that conservative fluid mixing models do not adequately describe fluid chemistries resulting from mixing of waters at the Äspö Hard Rock Laboratory. In particular, calcium, sodium, carbonate and sulfate were not conserved during fluid mixing. Viani and Bruton (1994) showed that fixed charge ion exchangers such as smectite can serve as sources and sinks of $\mathrm{Na}^{+}, \mathrm{Ca}^{++}$and $\mathrm{Mg}^{++}$, and may have 
contributed to non-conservative fluid mixing during the Large Scale Redox Experiment. It is also possible that variably charged solids such as oxyhydroxides of Fe can serve as sources and sinks of anions and cations and thus impact fluid chemistry.

A variety of cations (e.g. $\left.\mathrm{H}^{+}, \mathrm{Ca}^{++}, \mathrm{Sr}^{++}, \mathrm{Ba}^{++}\right)$and anions $\left(\mathrm{HCO}_{3}^{-}, \mathrm{SO}_{4}^{-}, \mathrm{HPO}_{4}^{-}\right)$ are known to sorb onto hydrous ferric oxides (HFOs) at $25^{\circ} \mathrm{C}$ (Dzombak and Morel, 1990). Hematite and Fe-oxyhydroxide are commonly found as fracture fillings at $\ddot{A} s p o ̈$ (e.g., Tullborg, 1995; Landstrom and Tullborg 1994). Banwart et al. (1994) estimated that the abundance of hematite in altered granite is $1-2 \%$, and that the abundance of Fe(III)oxyhydroxides in the fracture coatings is $4 \%$. Microfractures close to the fracture surface contain what appears to be iron oxyhydroxide. The ultimate goals of this work are to determine whether ion sorption onto HFOs during fluid mixing at Äspö can affect fluid chemistry, and to help test hypotheses regarding the mobility and partitioning of trace elements put forth by Landström and Tullborg (1995).

In this paper, we address the extent to which ion sorption and desorption can impact fluid chemistry at Äspö, and estimate the magnitude of the ion reservoirs (and sinks) represented by HFOs. An example will be shown of the effect on fluid chemistry of mixing of shallow and deep waters in the presence of HFOs at Äspö.

\section{APPROACH}

The approach in this paper is similar to that taken by Viani and Bruton (1994) to test the hypothesis that ion exchange affects the composition of groundwaters sampled from boreholes in the HRL tunnel. Geochemical modeling computer codes containing surface complexation models capable of simulating sorption onto HFOs were used to:

1) Calculate the potential for HFOs to serve as reservoirs and sinks of ions. The dependencies of ion sorption on $\mathrm{pH}$ in shallow and deep waters from the Redox Zone at Äspö were calculated to evaluate the potential for changes in major element chemistry . during fluid mixing owing to the sorptive behavior of HFOs.

2) Simulate mixing between the shallow and deep waters that are believed to contribute to the observed changes in fluid chemistry with time in the Large Scale Redox Experiment. Contributions from Baltic and modified Baltic sea waters, proposed by Skarman and Laaksoharju (pers. comm.), are not considered in this set of calculations.

\subsubsection{Surface complexation versus ion exchange}

Surface complexation refers to chemical reactions between reactive functional groups exposed on a solid surface and aqueous species in an adjacent fluid. Surface complexation reactions lead to the sorption and desorption of anions and cations. The reactive functional groups at the solid surface (often referred to as "sites") derive from unsatisfied bonds created by the discontinuity of a three-dimensional structure. 
The reactive sites on the surfaces of oxide minerals may be negative, neutral or positive depending on the extent of their protonation. Hence, the net charge on the surface may be positive or negative, depending on the $\mathrm{pH}$ of the solution. Oxide surfaces can therefore sorb anions as well as cations. In contrast, ion exchange minerals possess fixed amounts of charge imbalance, often imposed by the substitution of $\mathrm{Al}$ for $\mathrm{Si}$ in the mineral structure. The negative charge imbalance in cation exchangers restricts their exchange to cations. Hydrous ferric oxides with large specific surface areas on the order of $600 \mathrm{~m}^{2} / \mathrm{g}$ have a sorptive capacity roughly equivalent to that of smectite when related on a per mole of sorbent basis.

Both surface complexation and ion exchange reactions vary as a function of aqueous complexation in the fluid phase, ionic strength, and the solid:fluid ratio. Surface complexation varies as a function of electrostatic effects as well, whereas ion exchange is sensitive to steric constraints imposed by the structure of the ion exchanger. Because the charge of reactive sites in oxides is controlled by $\mathrm{pH}$, surface complexation reactions are much more sensitive to $\mathrm{pH}$ than ion exchange; the extent of ion sorption can change drastically within a few $\mathrm{pH}$ units.

\subsection{SURFACE COMPLEXATION MODELS}

The surface complexation reactions comprising the sorption model are provided for in the React geochemical modeling code. React is a part of The Geochemist's Workbench TM set of software tools for calculating fluid-mineral-gas equilibria. React combines the calculational abilities of EQ3 and $\mathrm{EQ} 6 . \mathrm{EQ} 3 / 6$, used by Viani and Bruton (1994) to describe ion exchange, could not be used as it does not provide for surface complexation reactions.

React can simultaneously provide for aqueous speciation in the fluid phase, mineral dissolution and precipitation, and surface complexation onto a sorbent, such as HFO. However, mineral dissolution and precipitation reactions were not considered in the calculations described in this paper.

React employs the generalized two-layer surface complexation model of Dzombak and Morel (1990). The generalized two-layer model is an extension of the diffuse double layer model, with provision for two types of sorption sites (weak and strong) and surface precipitation (see Dzombak and Morel, 1990 for an extensive discussion of the models).

\subsection{SIMULATION INPUT}

\subsubsection{Thermodynamic and sorption data}

Thermodynamic data for minerals, aqueous species and gases are contained in the React data base, which is sourced from an older version of the EQ $3 / 6$ data base called version R54. For the simulations described in this paper, however, the older data set should yield similar results to the current $\mathrm{EQ} 3 / 6$ data base GEMBOCH com.R22. 
React contains a data base of surface complexation constants from Dzombak and Morel (1990) assuming a generalized two-layer surface complexation model. Although the most comprehensive compilation of constants to date, Dzombak and Morel's data set lacks complexation constants for carbonate species.

At low $\mathrm{pH}$ values, anions such as sulfate and carbonate tend to be sorbed by HFOs. Preliminary calculations with Dzombak and Morel's data set suggested that sulfate surface complexes dominate the total mass of sulfate in the fluid+sorbent system. However, the Dzombak and Morel (1990) data set does not provide for competition between sulfate and carbonate for sorption sites. Therefore, a literature search was made to identify experimental studies yielding carbonate complexation constants that could be added to the Dzombak and Morel (1990) data set.

Waite et al. (1994) determined carbonate complexation constants as part of a larger study to measure U(VI) sorption onto HFOs. They used a two-site diffuse double layer model. Van Geen, Robertson and Leckie (1994) focused on complexation of carbonate species at the goethite surface, and used a single-site diffuse double layer model to extract . complexation constants from their sorption experiments.

The complexation constants from both papers were incorporated into two new versions of the React complexation constant data base from Dzombak and Morel (1990) (see Appendix A). Simulations were carried out with each of the three data bases (a) Dzombakand Morel (1990), (b) Dzombak and Morel plus carbonate complexation data. from Waite et al. (1994), and (c) Dzombak and Morel plus carbonate complexation data from Van Geen, Robertson and Leckie (1994) for comparison.

Scoping calculations using all three data bases suggested that the data of Van Geen, Robertson and Leckie (1994) predicted significantly' greater amounts of carbonate sorption than data from Waite et al. (1994). Van Geen, Robertson and Leckie's (1994) study also focused more closely on carbonate sorption than Waite et al. (1994). Thus, the two data bases from (a) Dzombak and Morel (1990) and (b) Dzombak and Morel plus carbonate complexation data from Van Geen, Robertson and Leckie were used to explore the impact of sorption on fluid chemistry in this contribution.

\subsubsection{Naming conventions for surface species}

In this paper, the naming conventions of Dzombak and Morel (1990) for surface complexes are used. "Weak" surface complexes are prefixed by " $>(w)$ ", whereas strong complexes are prefixed by " $>(s)$ " (see Dzombak and Morel (1990) for a complete discussion of these species).

No distinction was made between strong and weak sites in Van Geen, Robertson and Leckie's (1994) one-site model. Nonetheless, the data for carbonate surface species had to be input to the Dzombak and Morel data base using the two-site designations.

Accordingly, the complexation constants for strong and weak carbonate surface species 
are equal, and the concentrations of strong and weak complexes of the same species should be added together to obtain the total molality of that surface species.

\subsubsection{Solid sorbent}

For the calculations in this paper, goethite was used as a proxy for a variety of iron oxyhydroxides such as ferrihydrite and hematite that can act as sorbents. Goethite was assumed to contain 0.205 moles of sorption sites ( 0.2 weak, 0.005 strong) per mole of $\mathrm{Fe}$ (Dzombak and Morel, 1990). Iron oxyhydroxides can vary significantly in terms of their surface area and corresponding total number of surface sites per mole of Fe. However, by relating our calculations to the number of surface sites available for reaction, we obtain a common frame of reference for all forms of HFOs. The mass of goethite per kilogram of $\mathrm{H}_{2} \mathrm{O}$ was varied from 0.1 to $10 \mathrm{~g} / \mathrm{kg} \mathrm{H} \mathrm{H}_{2} \mathrm{O}$ to illustrate the effects of variations in sorbent:fluid ratio. The relations between mass of goethite, number of surface sites and fluid mass are discussed later in the paper.

\section{Fluid compositions}

Fluid sample HBH02-910912 (Banwart et al., 1992) was considered to be representative of shallow waters. The deep, native water was represented by fluid sample KA0483A910312 (Banwart et al., 1992). The scoping calculations described in this paper focus on major element chemistry; trace elements will be considered in future studies.

\section{SORPTION ONTO HFOS IN SHALLOW WATERS}

\subsubsection{Calculations using surface complexation data base excluding carbonate surface species}

The surface complexation reactions of goethite in HBHO2 water are shown in Figures 1a and $\mathrm{lb}$ as a function of $\mathrm{pH}$ using the carbonate surface species-free data base of Dzombak and Morel (1990). One gram of goethite, serving as a proxy for Fe-oxyhydroxides, was assumed to be in contact with $1 \mathrm{~kg}$ of $\mathrm{H}_{2} \mathrm{O}$ with the composition of $\mathrm{HBH} 02$. Figure 1a illustrates the tendency of ions to sorb and desorb as $\mathrm{pH}$ varies. The identity and quantity of the surface species contributing to the sorbed fraction is shown in Figure 1b.

Sorbed fraction in Figure 1a refers to the fraction of a given element that resides on HFO surfaces relative to the total amount of that element in the fluid+sorbent system. It is calculated as the sum of the concentrations of sorbed species containing a given element, divided by the sum of the amount of the element in solution and the amount of the element sorbed. For example, a sorbed fraction of 0.5 implies that if there are $100 \mathrm{mg} / \mathrm{kg}$ $\mathrm{SO}_{4}$ in solution, $100 \mathrm{mg} / \mathrm{kg} \mathrm{SO} 4$ are bound to the HFO surface as surface complexes. 
The sorbed fraction is a useful measure of the effectiveness of a sorbent as a reservoir of ions. When the sorbed fraction exceeds 0.5 , the mass of the sorbed element is greater than that in the fluid. A change in solution composition, such as $\mathrm{pH}$, could release those ions and significantly increase the ion concentration in the fluid.

Figures 1a and b suggest that a significant quantity of $\mathrm{SO}_{4}$ is associated with HFOs at pH values below neutral, even in the presence of only 1 gram of goethite. Surface complexation of $\mathrm{SO}_{4}$ at alkaline $\mathrm{pH}$ values is negligible. In keeping with the general rule in surface complexation (Dzombak and Morel, 1990), low pH favors somtion of anions, whereas high $\mathrm{pH}$ favors cation sorption. Figure $1 \mathrm{~b}$ shows the increase in the $\mathrm{SO}_{4}$-bearing surface species as $\mathrm{pH}$ decreases, and of the Ca-bearing species as $\mathrm{pH}$ increases. 


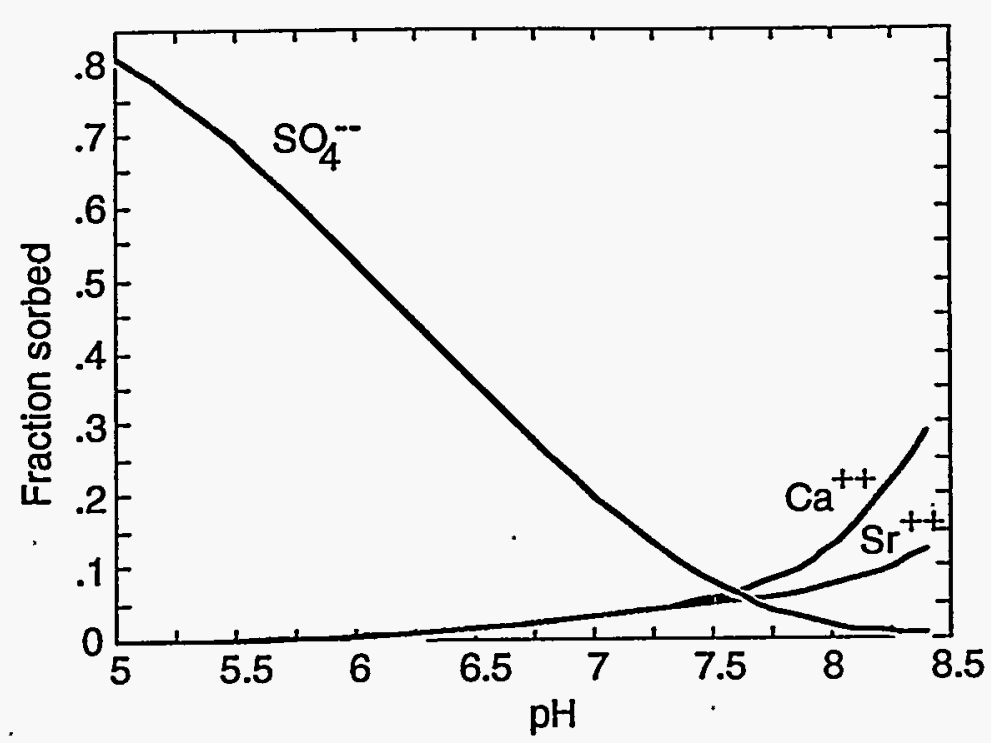

Figure 1a. Fraction of total quantity of $\mathrm{SO}_{4}, \mathrm{Ca}$ and $\mathrm{Sr}$ sorbed onto $1 \mathrm{~g}$ goethite $/ \mathrm{kg} \mathrm{H} \mathrm{H}_{2} \mathrm{O}$ in $\mathrm{HBH} 02$ water at $25^{\circ} \mathrm{C}$ using Dzombak and Morel (1990) surface complexation data base. Electrical balancing on $\mathrm{HCO}_{3}$.

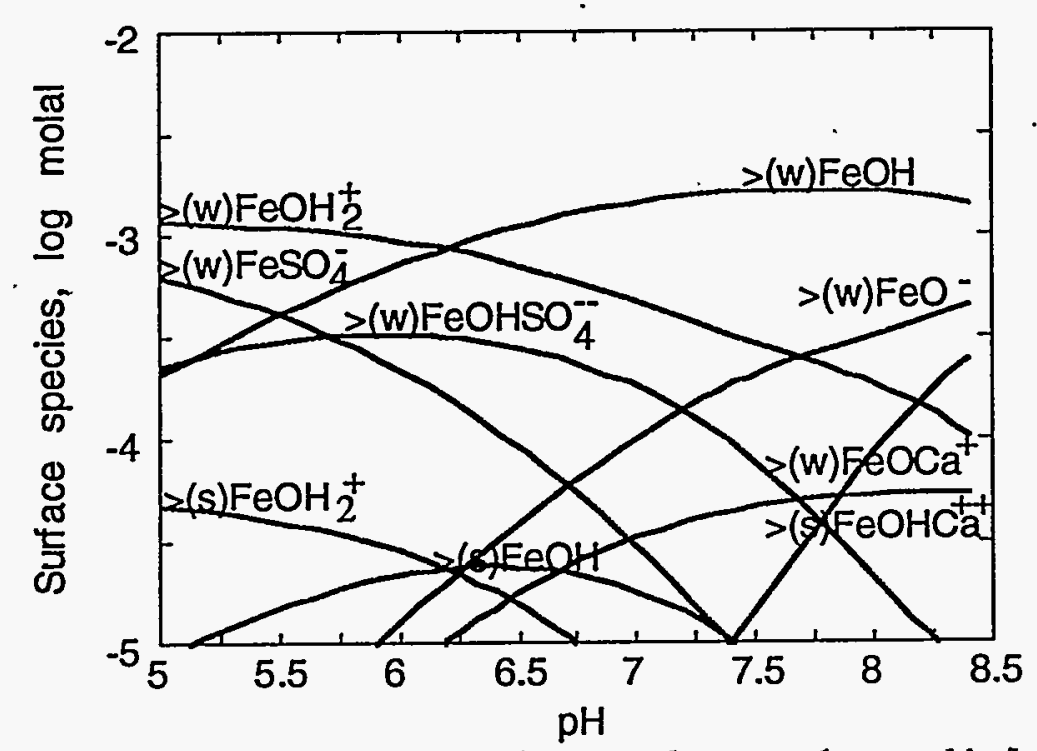

Figure $1 \mathrm{~b}$. Concentration of surface complexes on $1 \mathrm{~g}$ goethite $/ \mathrm{kg}$ $\mathrm{H}_{2} \mathrm{O}$ in $\mathrm{HBH} 02$ water at $25^{\circ} \mathrm{C}$ using Dzombak and Morel (1990) surface complexation data base. Electrical balancing on $\mathrm{HCO}_{3}$. Concentration of surface complexes expressed as moles of complex per $\mathrm{kg}$ of $\mathrm{H}_{2} \mathrm{O}$, i.e. molality. 
The impact of changing the sorbent:fluid ratio is addressed in Table 1, which shows the variation of sorbed fractions and concentrations of sorbed species as a function of the mass of goethite per kilogram of $\mathrm{H}_{2} \mathrm{O}$ for the carbonate surface species-free system. The fluid composition is that of $\mathrm{HBH} 02$ with its $\mathrm{pH}$ set at 6.6, as measured. Larger goethite:solution ratios increase the concentrations of sorbed ions and the fraction sorbed. Given 1 gram of goethite per kilogram $\mathrm{H}_{2} \mathrm{O}$, as much $\mathrm{SO}_{4}$ is sorbed on the solid as exists in solution. When the mass of goethite increases to 10 , the vast majority of $\mathrm{SO}_{4}$ in the fluid+HFO system resides on the goethite surface ( $216 \mathrm{vs} 20 \mathrm{mg} / \mathrm{kg}$ ).

Results for the shallow HBH02 water shown in Figures 1a and listed in Table 1 do not agree exactly because of differences in constraints used for the two sets of calculations. React, when calculating the reaction path that was represented by increasing the pH from 5 to 8.5 , included the sorbed fraction in the starting system at $\mathrm{pH}=5$ as part of the total elemental mass in the system: As pH increases, anions such as $\mathrm{SO}_{4}$ are released and cause the fluid composition to deviate from that of $\mathrm{HBH} 02$. Nonetheless, figures such as Figure la demonstrate the expected trends in sorptive behavior with $\mathrm{pH}$. The effect in the deeper KA0483A waters is less pronounced because the calculated sorbed fraction at the starting $\mathrm{pH}$ of 5 is lower, and thus a smaller reservoir of ions is available to contribute to changes in solution composition.

\subsubsection{Calculations using surface complexation data base including. carbonate surface species}

For comparison to Figures $1 \mathrm{a}$ and $1 \mathrm{~b}$, the same calculations as above were made incorporating data for the carbonate surface species from Van Geen, Robertson and Leckie (1994) into the Dzombak and Morel (1990) data base. These results are shown in Figures $2 \mathrm{a}$ and $2 \mathrm{~b}$ and Table 2. It is apparent that carbonate species are sorbed at the expense of sulfate. Sulfate surface complexes drop to low concentrations because of competition from carbonate for surface sites. Carbonate surface complexes comprise a significant fraction of total carbonate in the fluid+sorbent system. For example, Table 2 shows that over 10 times as much carbonate (1121 mg/kg expressed as bicarbonate) is sorbed onto HFO surfaces as is contained in the fluid $(114 \mathrm{mg} / \mathrm{kg})$ given a sorbent:fluid ration of $10 \mathrm{~g}$ of goethite per kilogram of $\mathrm{H}_{2} \mathrm{O}$. Thus, the calculations suggest that HFOs at shallow depths may serve as important reservoirs or sources of carbonate if conditions, such as an increase in $\mathrm{pH}$, favor desorption of carbonate. 


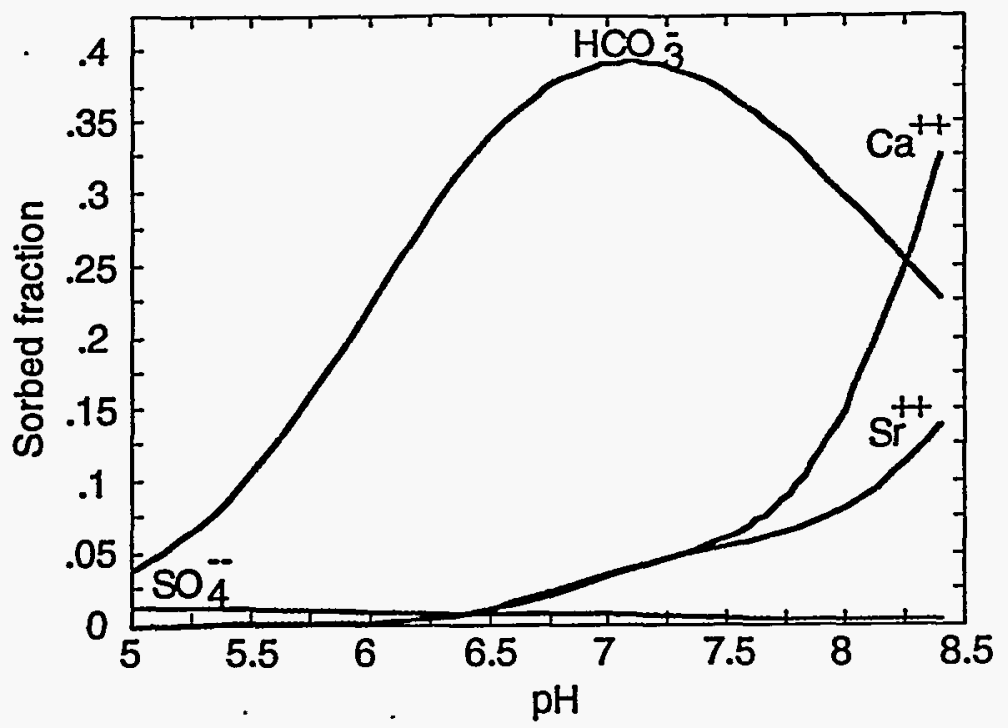

Figure 2a. Fraction of total quantity of $\mathrm{HCO}_{3}, \mathrm{SO}_{4}, \mathrm{Ca}$ and $\mathrm{Sr}$ sorbed onto $1 \mathrm{~g}$ goethite $/ \mathrm{kg} \mathrm{H} 2 \mathrm{O}$ in $\mathrm{HBH} 02$ water at $25^{\circ} \mathrm{C}$ using Dzombak and Morel (1990) surface complexation data . with carbonate surface species from Van Geen, Robertson and Leckie (1994). Electrical balancing on $\mathrm{HCO}_{3}$. 


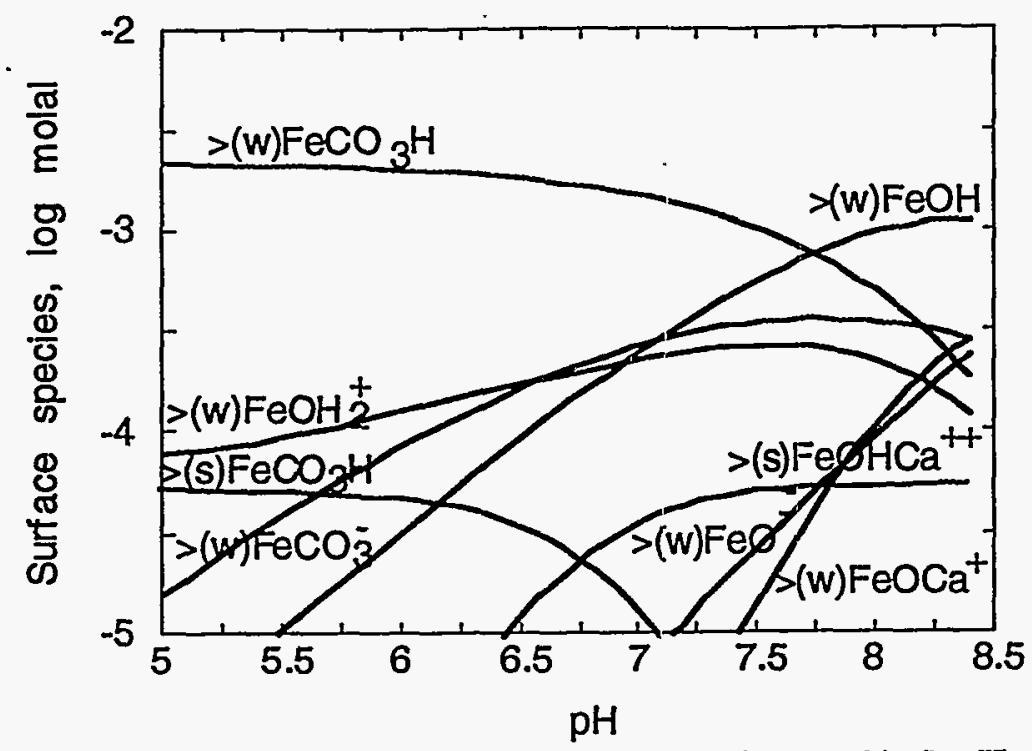

Figure $2 \mathrm{~b}$. Concentration of surface complexes on $1 \mathrm{~g}$ goethite/kg $\mathrm{H}_{2} \mathrm{O}$ in HBH02 water at $25^{\circ} \mathrm{C}$ using Dzombak and Morel (1990) data with carbonate surface species from Van Geen, Robertson and Leckie (1994). Electrical balancing on $\mathrm{HCO}_{3}$. Concentration of surface complexes expressed as moles of complex per $\mathrm{kg}$ of $\mathrm{H}_{2} \mathrm{O}$, i.e. molality.

Table 1. Predicted sorbed fractions and concentrations of $\mathrm{Ca}, \mathrm{Sr}$ and $\mathrm{SO}_{4}$ (in $\mathrm{mg} / \mathrm{kg}$ ) in HBH02 as a function of mass of goethite $/ \mathrm{kg} \mathrm{H} \mathrm{H}_{2} \mathrm{O}$. Calculated using Dzombak and Morel (1990) surface complexation data base.

\begin{tabular}{|l|l|l|l|}
\hline $\begin{array}{l}\text { Mass of goethite } \\
(\mathrm{g} / \mathrm{kg} \mathrm{H} \mathrm{O})\end{array}$ & \multicolumn{3}{|l|}{$\begin{array}{l}\text { Predicted sorbed fraction and concentration (in } \\
\text { parentheses) of sorbed species. Concentrations } \\
\text { expressed in } \mathrm{mg} / \mathrm{kg} .\end{array}$} \\
\hline & $\mathrm{Ca}$ & $\mathrm{Sr}$ & $\mathrm{SO}$ \\
\hline 0.1 & 0.0013 & $0.0014(0.0002)$ & 0.1 \\
& $(0.057)$ & & $(2.2)$ \\
\hline 1 & 0.013 & 0.014 & 0.53 \\
& $(0.57)$ & $(0.002)$ & $(21.7)$ \\
\hline 10 & 0.12 & 0.12 & 0.92 \\
& $(5.66)$ & $(0.02)$ & $(215.7)$ \\
\hline & & & \\
\hline $\begin{array}{l}\text { Concentration in } \\
\text { coexisting fluid phase, } \\
\text { mg/kg }\end{array}$ & 42.8 & 0.16 & 19.5 \\
\hline
\end{tabular}


Table 2. Predicted sorbed fractions and concentrations of sorbed $\mathrm{Ca}, \mathrm{Sr}, \mathrm{SO}_{4}$ and $\mathrm{HCO}_{3}$, in $\mathrm{mg} / \mathrm{kg}$, in $\mathrm{HBHO} 2$ as a function of mass of goethite $/ \mathrm{kg} \mathrm{H} \mathrm{H}_{2} \mathrm{O}$. Calculated using Dzombak and Morel (1990) surface complexation data base with carbonate complexation constants from Van Geen, Robertson and Leckie (1994).

\begin{tabular}{|l|l|l|l|l|}
\hline $\begin{array}{l}\text { Mass of goethite } \\
\text { (g/kg H2O) }\end{array}$ & \multicolumn{4}{|l|}{$\begin{array}{l}\text { Predicted sorbed fraction and concentration (in } \\
\text { parentheses) of sorbed species. Concentrations expressed } \\
\text { in mg/kg. }\end{array}$} \\
\hline & $\mathrm{Ca}$ & $\mathrm{Sr}$ & $\mathrm{SO} 4$ & $\mathrm{HCO}$ \\
\hline 0.1 & 0.0015 & 0.0016 & 0.0022 & 0.09 \\
& $(0.06)$ & $(0.0003)$ & $(0.04)$ & $(11.21)$ \\
\hline 1 & 0.015 & 0.016 & 0.022 & 0.50 \\
& $(0.63)$ & $(0.003)$ & $(0.43)$ & $(112.1)$ \\
\hline 10 & 0.13 & 0.14 & 0.18 & 0.91 \\
& $(6.31)$ & $(0.03)$ & $(4.31)$ & $(1121)$ \\
\hline & & & & \\
\hline $\begin{array}{l}\text { Concentration in } \\
\text { coexisting fluid phase, } \\
\text { mg/kg }\end{array}$ & 42.8 & 0.16 & 19.5 & 114. \\
\hline
\end{tabular}




\subsubsection{Calculations using surface complexation data base excluding carbonate surface species}

The elements predicted to be sorbed onto goethite in equilibrium with KA0483A water are shown in Figure $3 \mathrm{a}$ as a function of $\mathrm{pH}$ using the carbonate surface species-free data base of Dzombak and Morel (1990). 1 gram of goethite was assumed to be in contact with $1 \mathrm{~kg}$ of $\mathrm{H}_{2} \mathrm{O}$ with the solution composition of $\mathrm{KA0483A}$. The identity and molality of the surface species as a function of $\mathrm{pH}$ are shown in Figure $3 \mathrm{~b}$. Table 3 summarizes the predicted sorbed fractions and the concentrations of sorbed components as a function of the sorbent:fluid ratio.

Predicted sorbed fractions for $\mathrm{Ca}$, $\mathrm{Sr}$ and $\mathrm{SO}_{4}$ (Table 3) are less than those predicted for HBH02 (Table 1), aithough the concentrations of sorbed species are larger for a given sorbent:fluid ratio. $\mathrm{KA0483A}$ water contains less $\mathrm{HCO}_{3}$ than $\mathrm{HBH} 02$, but greater quantities of $\mathrm{Ca}$ and $\mathrm{SO}_{4}$ : Thus, even though the calculated sorbed fraction of $\mathrm{Ca}$ and $\mathrm{SO}_{4}$ may be less than that predicted to be in equilibrium with $\mathrm{HBH} 02$, the absolute quantities of sorbed species may actually be greater. For example, greater quantities of $\mathrm{Ca}$ are sorbed at alkaline $\mathrm{pH}$ onto HFO in equilibrium with $\mathrm{KA} 0483 \mathrm{~A}$, but the calculated sorbed fraction of $\mathrm{Ca}$ is less than that predicted for $\mathrm{HBH} 02$ because $\mathrm{KA} 0483 \mathrm{~A}$ waters contain more $\mathrm{Ca}$. The above discussion demonstrates that predicted sorbed fractions must be interpreted with care.

\subsubsection{Calculations using surface complexation data base including carbonate surface species}

The impact of including carbonate surface species using data from Van Geen, Robertson and Leckie (1994) is shown in Figures $4 \mathrm{a}$ and $4 \mathrm{~b}$ for comparison. Table 4 details the predicted sorbed fraction and the concentrations of sorbed components as a function of the sorbent:fluid ratio. As in the HBHO2 simulations, the sorbed fraction of carbonate surface complexes dominates that of sulfate complexes. The sorbed fraction of carbonate exceeds 0.5 when the mass of goethite exceeds 1 gram per kilogram of $\mathrm{H}_{2} \mathrm{O}$. This means that a greater reservoir of carbonate may be associated with HFOs than with the fluid, as was predicted for HFOs in equilibrium with $\mathrm{HBHO2}$ water. 


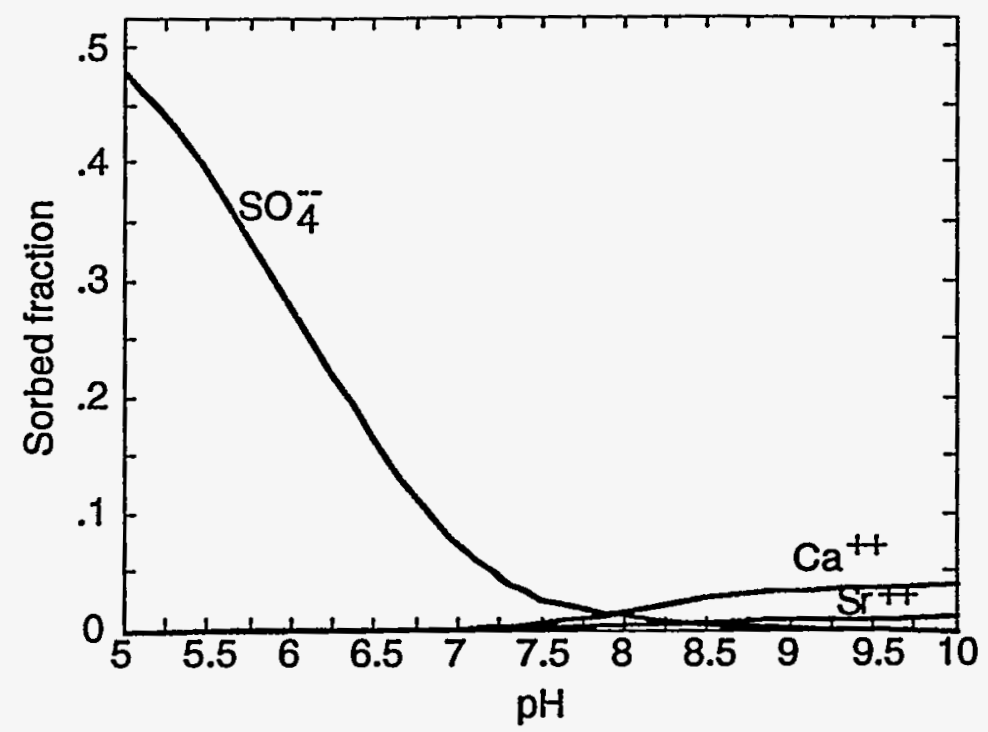

Figure 3a. Fraction of total quantity of $\mathrm{SO}_{4}, \mathrm{Ca}$ and $\mathrm{Sr}$ sorbed onto $1 \mathrm{~g}$ goethite/kg $\mathrm{H}_{2} \mathrm{O}$ in $\mathrm{HBHO}_{2}$ $25^{\circ} \mathrm{C}$ using Dzombak and Morel (1990) surface complexation data base. Electrical balancing on $\mathrm{Cl}$.

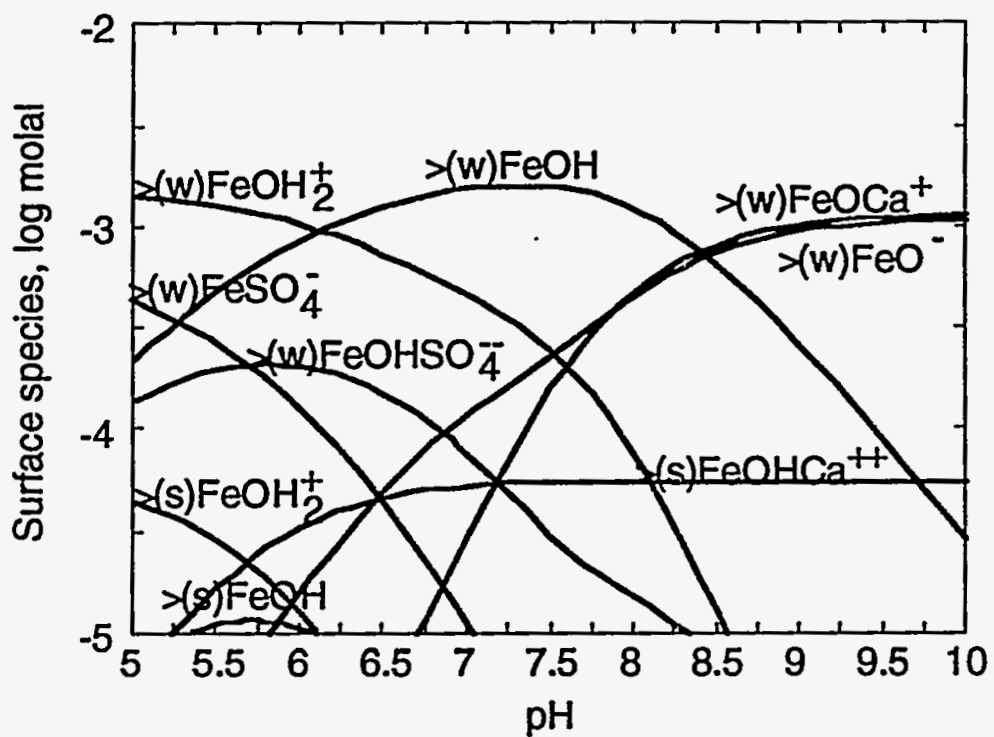

Figure $3 \mathrm{~b}$. Concentration of surface complexes on $1 \mathrm{~g}$ goethite/ KA0483A water at $25^{\circ} \mathrm{C}$ using Dzombak and Morel (199 complexation data base. Electrical balancing on Cl. Concentration complexes expressed as moles of complex per $\mathrm{kg}$ of $\mathrm{H}_{2} \mathrm{O}$, i.e. molal 


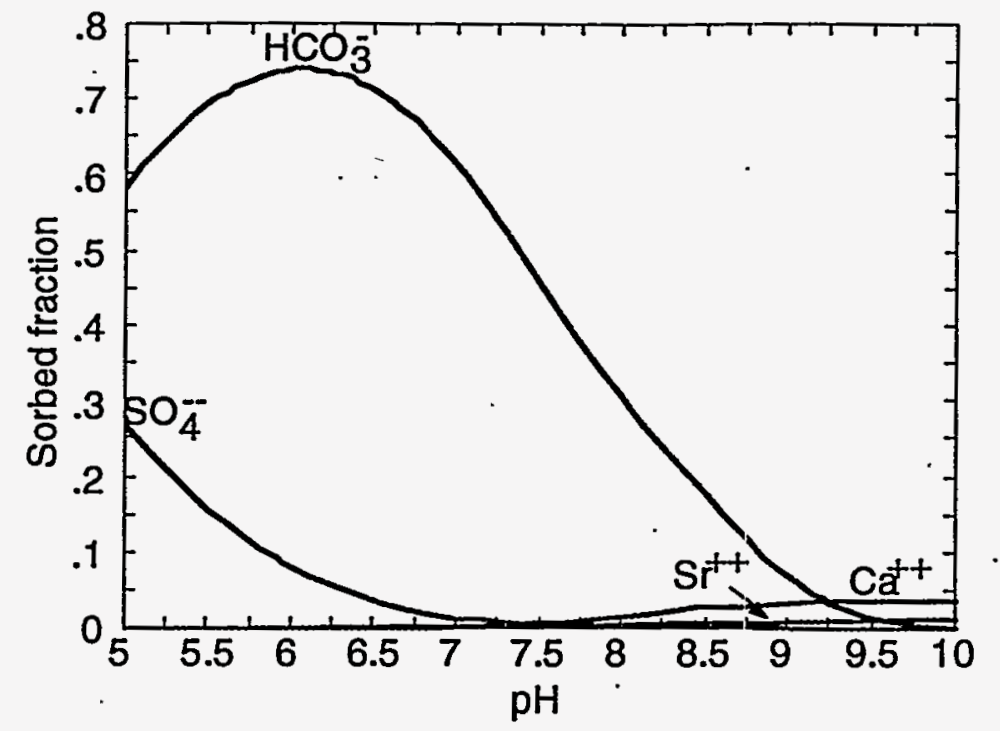

Figure 4a. Fraction of total quantity of $\mathrm{HCO}_{3}, \mathrm{SO}_{4}, \mathrm{Ca}$ and $\mathrm{Sr}$ sorbed

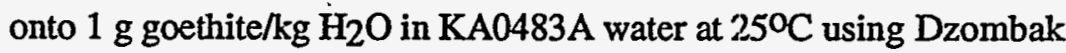
and Morel (1990) surface complexation data with carbonate surface species from Van Geen, Robertson and Leclie (1994). Electrical balancing on $\mathrm{Cl}$.

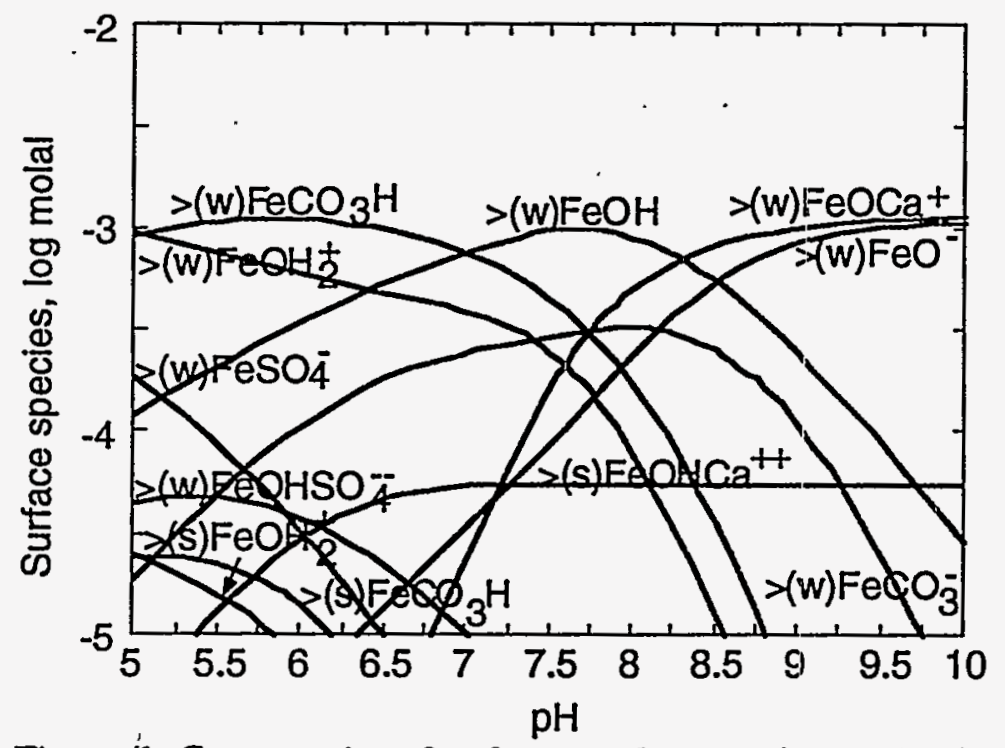

Figure 4b. Concentration of surface complexes on $1 \mathrm{~g}$ goethite $/ \mathrm{kg} \mathrm{H}_{2} \mathrm{O}$ in KA0483A water at $25^{\circ} \mathrm{C}$ using Dzombak and Morel (1990) data with carbonate surface species from Van Geen, Robertson and Leckie (1994). Electrical balancing on $\mathrm{Cl}$. Concentration of surface complexes expressed as moles of complex per $\mathrm{kg}$ of $\mathrm{H}_{2} \mathrm{O}$, i.e. molality. 
Table 3. Predicted sorbed fractions and concentrations of sorbed $\mathrm{Ca}, \mathrm{Sr}$ and

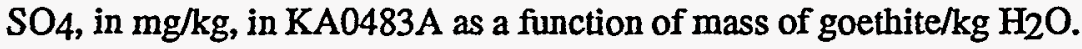
Calculated using Dzombak and Morel (1990) surface complexation data base.

\begin{tabular}{|l|l|l|l|}
\hline $\begin{array}{l}\text { Mass of goethite } \\
(\mathrm{g} / \mathrm{kg} \mathrm{H} \mathrm{O})\end{array}$ & \multicolumn{3}{|l|}{$\begin{array}{l}\text { Predicted sorbed fraction and concentration } \\
\text { (in parentheses) of sorbed species. } \\
\text { Concentrations expressed in } \mathrm{mg} / \mathrm{kg} .\end{array}$} \\
\hline & $\mathrm{Ca}$ & $\mathrm{Sr}$ & $\mathrm{SO} 4$ \\
\hline 0.1 & 0.0007 & 0.0003 & 0.003 \\
& $(0.83)$ & $(0.0007$ & $(0.18)$ \\
\hline 1 & 0.007 & 0.003 & 0.029 \\
& $(8.33)$. & $(0.07)$ & $(1.79)$ \\
\hline 10 & 0.063 & 0.03 & 0.23 \\
& $(83.15) \cdot$ & $(0.68)$ & $(17.82)$ \\
\hline & & & \\
\hline $\begin{array}{l}\text { Concentration in } \\
\text { coexisting fluid phase, } \\
\text { mg/kg }\end{array}$ & 1250 & 21.5 & 60 \\
\hline
\end{tabular}

Table 4. Predicted sorbed fractions and concentrations of sorbed $\mathrm{Ca}, \mathrm{Sr}, \mathrm{SO} 4$ and $\mathrm{HCO}_{3}$, in $\mathrm{mg} / \mathrm{kg}$, as a function of mass of goethite $/ \mathrm{kg} \mathrm{H} 2 \mathrm{O}$ in $\mathrm{KA0483A}$.

Calculated using Dzombak and Morel (1990) surface complexation data base with carbonate complexation constants from Van Geen, Robertson and Leckie (1994).

\begin{tabular}{|l|l|l|l|l|}
\hline $\left.\begin{array}{l}\text { Mass of goethite } \\
(\mathrm{g} / \mathrm{kg} \mathrm{H}\end{array} \mathrm{O}\right)$ & \multicolumn{4}{|l|}{$\begin{array}{l}\text { Predicted sorbed fraction and concentration (in } \\
\text { parentheses) of sorbed species. Concentrations expressed } \\
\text { in mg/kg. }\end{array}$} \\
\hline & $\mathrm{Ca}$ & $\mathrm{Sr}$ & $\mathrm{SO}$ & $\mathrm{HCO} 3$ \\
\hline 0.1 & 0.0007 & 0.0003 & 0.0008 & 0.09 \\
& $(0.87)$ & $(0.007)$ & $(0.05)$ & $(3.96)$ \\
\hline 1 & 0.007 & 0.003 & 0.008 & 0.49 \\
& $(8.7)$ & $(0.07)$ & $(0.5)$ & $(39.6)$ \\
\hline 10 & 0.066 & 0.032 & 0.078 & 0.91 \\
& $(87)$ & $(0.7)$ & $(5)$ & $(396)$ \\
\hline & & & & \\
\hline $\begin{array}{l}\text { Concentration in } \\
\text { coexisting fluid phase, } \\
\text { mg/kg }\end{array}$ & 1250 & 21.5 & 60 & 42 \\
\hline
\end{tabular}


In order to relate the caiculations described in this paper to attributes of natural systems, we must establish the relevance of the masses of goethite used per $\mathrm{kg} \mathrm{H}_{2} \mathrm{O}$. For a given fracture width, we calculated the thickness of a continuous goethite fracture coating yielding $0.1,1$ and 10 grams of goethite per $\mathrm{kg} \mathrm{H}_{2} \mathrm{O}$, assuming a fully saturated system (Figure 5). The number of surface sites corresponding to $0.1,1$, and 10 grams of goethite are also shown in Figure 5.

Given the abundance and distribution of HFOs observed at Äspö, the quantities of goethite used per $\mathrm{kg}$ of $\mathrm{H}_{2} \mathrm{O}$ seem reasonable. The masses of goethite used in the calculations were not, however, originally selected through an analysis of HFO occurrence at Äspö. Even though the goethite does not form continuous surface layers in nature, the calculation nonetheless demonstrates that the masses of goethite considered in this report are conservative, yet account for a great deal of surface complexation.

The number of sites available for surface complexation reactions was calculated assuming $0.205 \mathrm{~mol}$ of sites $/ \mathrm{mol} \mathrm{Fe}$, which is equal to $0.205 \mathrm{~mol}$ sites/mol goethite (Dzombak and Morel, 1990). This is equivalent to $2.31 \times 10^{-3}$ moles of surface sites per gram of goethite.

The results of geochemical simulations such as those described in this paper are only as reliable as the surface complexation constants and the complexation model upon which the predictions are based. For example, the carbonate complexation constants from Van Geen, Robertson and Leckie (1994) may overestimate the degree of formation of surface carbonate complexes. If so, the degree of $\mathrm{SO}_{4}$ sorption would increase.

The reliability and robustness of surface complexation models and their data bases in simulating controlled and natural systems has not yet been explored fully. The results in this paper should therefore not be used at this time as absolute, quantitative predictions of system behavior, but rather as a guide to how systems will behave in response to a change in the physical and/or chemical state such as induced by fluid mixing or changes in $\mathrm{pH}$ and redox state. 


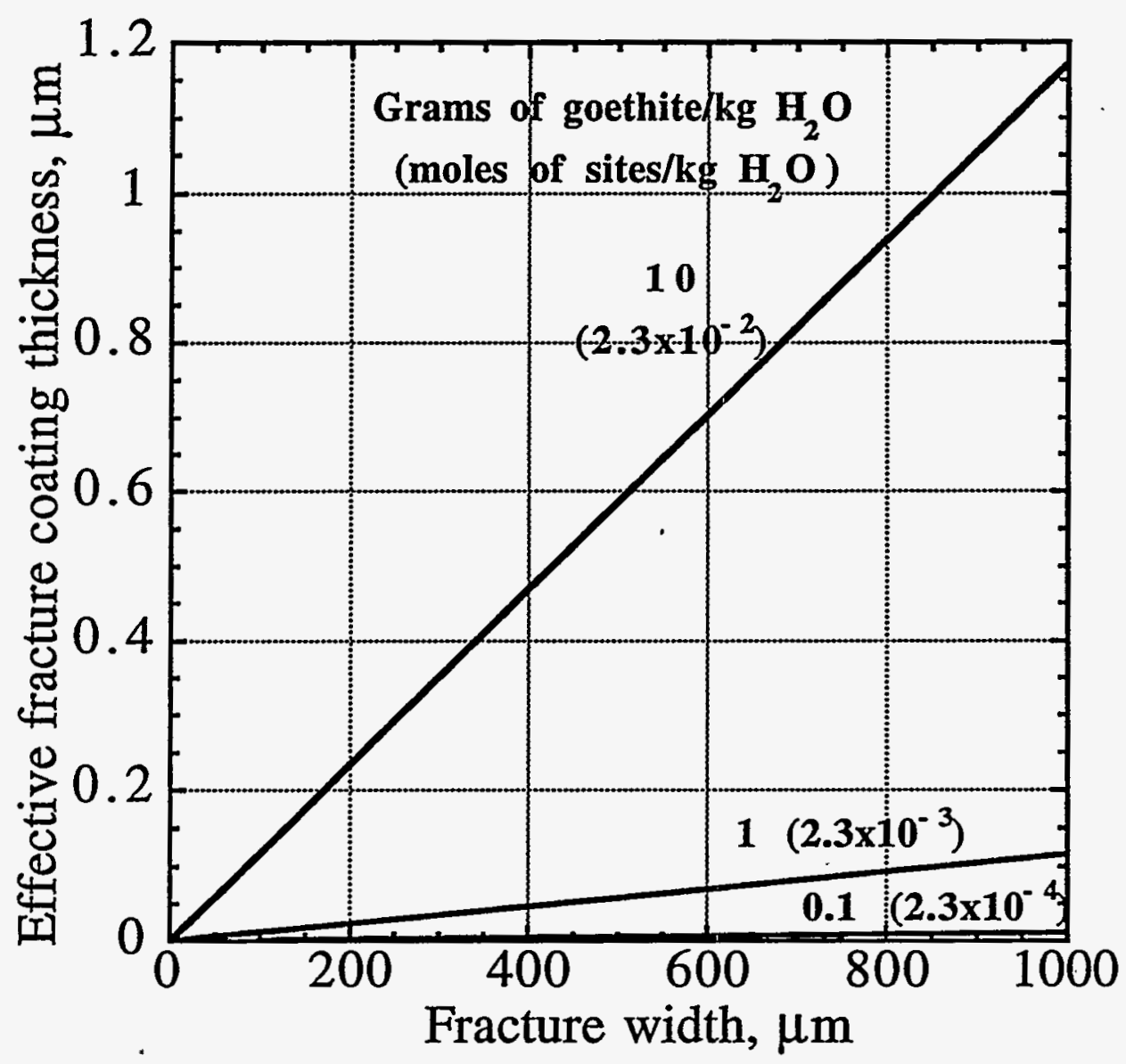

Figure 5. Effective thickness of fracture coating of goethite required to allow $0.1,1$ and 10 grams of goethite to contact $1 \mathrm{~kg}$ of $\mathrm{H}_{2} \mathrm{O}$ contained within the fracture. Corresponding moles of surface sites $/ \mathrm{kg}$ of $\mathrm{H}_{2} \mathrm{O}$ also shown for reference. 


\section{METHOD}

The mixing of a shallow water represented by HBH02-910912 (Banwart et al., 1992) and a deep native water represented by KA0483A-910312 (Banwart et al., 1992) was simulated with the computer code React (Bethke, 1994). The end member waters are the same as those used by Viani and Bruton (1994).

Fuid mixing in React was conducted differently than in Viani and Bruton (1994), who used EQ3/6, owing to differences in code capabilities. In React, the mixing of increasing amounts of shallow fluid (HBH02) into the deep fluid (KA0483A) was simulated by

1) specifying the composition of the deep fluid per $\mathrm{kg}$ of solvent $\left(\mathrm{H}_{2} \mathrm{O}\right)$.

2) specifying the mass and composition of the shallow fluid that will be gradually mixed with the deep fluid.

3) removing or "flushing" from the system a mass of the deep fluid/shallow fluid mixture equivalent to each increment of shallow fluid that is added, to retain a total mass of $\mathrm{H}_{2} \mathrm{O}$ of $1 \mathrm{~kg}$. (In the EQ3/6 simulation of Viani and Bruton (1994), an equivalent mass of the original, unmixed deep fluid was removed.)

Ten $\mathrm{kg}$ of the shallow fluid were flushed into $1 \mathrm{~kg}$ of the deep water system. This mass was chosen so that the final ionic strength is close to that of the shallow fluid. Fluid mixing was assumed to occur in the presence of 1 gram of goethite per kilogram of $\mathrm{H}_{2} \mathrm{O}$.

\section{RESULTS}

The predicted concentrations of $\mathrm{Ca}, \mathrm{Sr}$ and $\mathrm{SO}_{4}$ in the aqueous phase do not vary significantly from the concentrations that are predicted using a conservative fluid mixing model. Results for $\mathrm{HCO}_{3}$ are more difficult to interpret and cannot be addressed adequately at this time. However, it appears that for major elements such as $\mathrm{Ca}$ and $\mathrm{SO}_{4}$, surface complexation onto HFOs during mixing of shallow and deep waters does not account for observed deviations from a conservative mixing model, at least for the ranges of sorbent:fluid used in the calculations.

Future studies will explore the impact of fluid mixing on the distributions of trace elements such as uranium at $\ddot{A}$ spö. 
Hydrous ferric oxides are important sources and sinks of carbonate in both the shallow and deep, native waters at Äspö through surface complexation. Carbonate surface complexation is favored over sulfate surface complexation at neutral to acid pH. Ca and Sr sorption increase as $\mathrm{pH}$ increases.

Geochemical modeling of surface complexation on goethite, used as a proxy for HFOs, suggests that a greater reservoir of carbonate may be associated with HFOs than with the fluid. For example, 1 to 20 times the mass of aqueous carbonate can be sorbed onto 1 to 10 grams of goethite in approximately $1 \mathrm{~kg}$ of both shallow HBH02 and deep KA0483A water. Thus, HFOs may serve as important sources and sinks of carbonate.

Comparatively small amounts of $\mathrm{Ca}$ and $\mathrm{Sr}$ are sorbed from the shallow $\mathrm{HBHO} 2$ water and the deep KA0483A water.

The sorbent:fluid ratios used to evaluate the effects of sorption on fluid chemistry are consistent with observations of HFO abundance at Äspö. Geochemical simulations of mixing between HBH02 and KA0483A waters suggest that major elements such as $\mathrm{Ca}$, $\mathrm{Sr}$ and $\mathrm{SO}_{4}$ are not significantly affected by surface complexation onto HFOs. Thus, surface complexation does not account for observed deviations from a conservative mixing model for $\mathrm{Ca}$ and $\mathrm{SO}_{4}$, at least for the ranges of sorbent:fluid ratios used in the calculations.

Future studies should explore the impact of fluid mixing on the distributions of trace elements such as uranium at Äspö. A sorption data base for uranium is available (Waite et al., 1994), but effort will be required to develop or estimate sorption data for other trace elements that have been measured in Äspö waters (e.g., Nilsson, 1995).

\section{ACKNOWLEDGMENTS}

This work was performed under the auspices of the U.S. Department of Energy by Lawrence Livermore National Laboratory under Contract W-7405-ENG-48. Financial support for this project was provided by the Geochemical Modeling activity of the Hard Rock Laboratory (HRL) Project Agreement between the U.S. Department of Energy and the Swedish Nuclear Fuel and Waste Management Company. 
Banwart, S., Laaksoharju, M., Nilsson, A-C., Tullborg, E-L. and Wallin, B., 1992. The Large Scale Redox Experiment: Initial characterization of the fracture zone, SKB Äspö Hard Rock Laboratory Progress Report 25-92-04, Stockholm.

Banwart, S., Gustafsson, E., Laaksoharju, M., Nilsson, A-C., Tullborg, E-L. and Wallin, B., 1994. Large-scale intrusion of shallow water into a vertical fracture zone in crystalline bedrock: Initial hydrochemical perturbation during tunnel construction at the Äspö Hard Rock Laboratory, southeastern Sweden. Water Resources Res., v. 30, p. 1747-1763.

Laaksoharju, M., 1994. Mixing calculations: A first step in the modeling of a natural groundwater system. In Banwart, S., ed., Proc. Äspö International Geochemistry Workshop, June 2-3,1994, Äspö Hard Rock Laboratory, p. B-57-B-66.

Landström, O. and Tullborg, E-L., 1995. Interactions of U, Th, REE, Ra, Cs and Sr with clay minerals, Fe-oxyhydroxide and calcite, draft.

Nilsson, A-C., 1995. Compilation of groundwater chemistry data from Äspö: 1990 1994, SKB Äspö Hard Rock Laboratory Progress Report 25-95-02, Stockholm.

Tullborg, E-L., 1995, Mineralogical and chemical data on rocks and fracture minerals from Äspö, Äspë Hard Rock Laboratory Technical Note 25-95-07g, Stockholm.

Van Geen, A., Robertson, A.P. and Leckie, J.O., 1994. Complexation of carbonate species at the goethite surface: Implications for adsorption of metal ions in natural waters. . Geochim. et Cosmochim. Acta, v. 58, p. 2073-2085.

Viani, B.E. and Bruton, C.J., 1994. Effect of cation exchange on major cation chemistry in the Large Scale Redox Experiment at Äspö. In Banwart, S., ed., Proc. Äspö International Geochemistry Workshop, June 2-3, 1994, Äspö Hard Rock Laboratory, p. B-78-B-96.

Waite, T.D., Davis, J.A., Payne, T.E., Waychunas, G.A. and Xu, N., 1994. Uranium(VI) adsorption to ferrihydrite: Application of a surface complexation model, Geochim. et Cosmochim. Acta, v. 58, p. 5465-5478. 


\section{Appendix A. Surface complexation constants (K)}

\begin{tabular}{|c|c|c|c|}
\hline & \multicolumn{3}{|l|}{$\log K$} \\
\hline Surface complexation reaction & $\begin{array}{l}\text { Dzombak } \\
\text { and Morel }\end{array}$ & $\begin{array}{l}\text { Waite et al. } \\
\mathrm{I}=0.1\end{array}$ & $\begin{array}{l}\text { Van Geen et } \\
\text { al.- intrinsic }\end{array}$ \\
\hline$>\mathrm{FeOH}+\mathrm{H}^{+}=>\mathrm{FeOH}_{2}^{+}$ & $7.29^{*}$ & $6.51^{*}$ & 7.91 \\
\hline$>\mathrm{FeOH}=\mathrm{FeO}^{-}+\mathrm{H}^{+}$ & $-8.93^{*}$ & $-9.13^{*}$ & -10.02 \\
\hline $\begin{array}{l}>\mathrm{FeOH}+\mathrm{H}^{+}+\mathrm{HCO}_{3}^{-}= \\
\mathrm{FeCO}_{3} \mathrm{H}^{0}+\mathrm{H}_{2} \mathrm{O}\end{array}$ & - & $9.266^{*}$ & 10.45 \\
\hline $\begin{array}{l}>\mathrm{FeOH}+\mathrm{HCO}_{3}^{-}=\mathrm{FeCO}_{3}^{-}+ \\
\mathrm{H}_{2} \mathrm{O}\end{array}$ & - & $1.276^{*}$ & 2.38 \\
\hline Model & $\begin{array}{l}\text { Gen. Diffuse } \\
\text { double layer; } \\
\text { 2-site } \\
\end{array}$ & $\begin{array}{l}\text { Diffuse } \\
\text { double layer; } \\
\text { 2-site } \\
\end{array}$ & \begin{tabular}{|l|} 
Diffuse \\
double layer; \\
1-site
\end{tabular} \\
\hline Site density & 2.3 sites $/ \mathrm{nm}^{2}$ & $\begin{array}{l}9.88 \\
\text { sites/nm² } \\
(\text { calc.)** }\end{array}$ & 2.3 sites $/ \mathrm{nm}^{2}$ \\
\hline Sites & $\begin{array}{l}0.205 \\
\mathrm{~mol} / \mathrm{mol} \mathrm{Fe} ; \\
0.2 \mathrm{w}, 0.005 \mathrm{~s} \\
\end{array}$ & $\begin{array}{l}0.875 \\
\mathrm{~mol} / \mathrm{mol} \\
\mathrm{Fe} ; 0.0018 \mathrm{w}\end{array}$ & $\begin{array}{l}0.015 \\
\mathrm{~mol} / \mathrm{mol} \mathrm{Fe} \\
(\mathrm{calc} .)^{* *}\end{array}$ \\
\hline Surface area & $600 \mathrm{~m}^{2} / \mathrm{g}$ & $600 \mathrm{~m}^{2} / \mathrm{g}$ & $45 \mathrm{~m}^{2} / \mathrm{g}$ \\
\hline
\end{tabular}

* reaction constants for weak and strong surface sites assumed to be equal ** calculated from data in paper 
